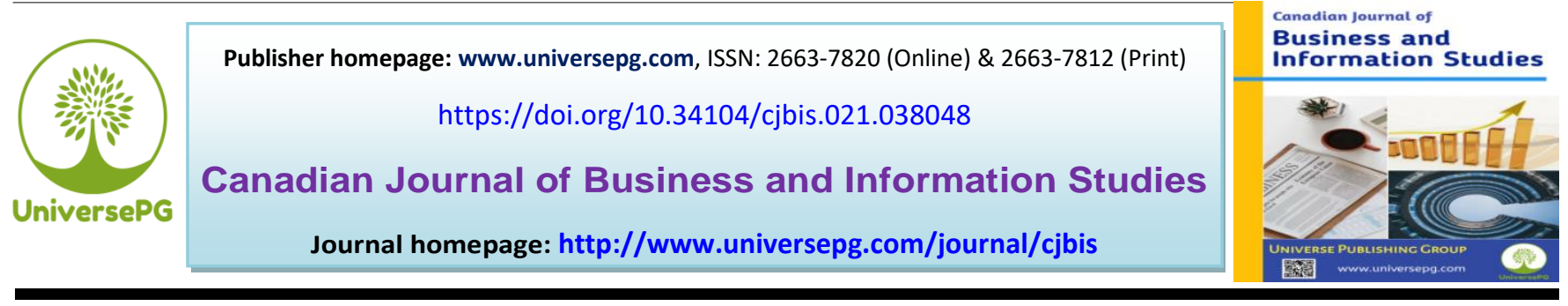

\title{
Factors Affecting Work-Life Balance of Women in Bangladesh: A Study during COVID-19 Pandemic
}

\author{
Sangita Basak* \\ Department of Management Studies, Comilla University, Cumilla-3506, Bangladesh. \\ *Correspondence: sangitamgtcou@ gmail.com (Sangita Basak, Lecturer, Department of Management Studies, Comilla \\ University, Cumilla-3506, Bangladesh).
}

\begin{abstract}
Throughout history, the central role of women in society has ensured stability, progress, and long-term development. Women are the primary caretaker of children and elders in every society. In the contemporary world, women are no longer lag behind in terms of career. They are keeping themselves shoulder to shoulder with their opposite sex. In Bangladesh, a large portion of economic activities is carried out by women including household and care activities, agriculture, education, industries, banking, and service sectors. This study aims to identify the factors that affect maintaining the proper work-life balance of working women in Bangladesh during COVID-19 pandemic. To pursue this objective, hundred and five (105) women from the different profession (Teaching, Banking, Healthcare, Ready Made Garments Industries, Public and Private Corporations, Government Service and Entrepreneur) have randomly selected from Dhaka and Chattagram division, Bangladesh. Collected data have tested with the help of various statistical tools like reliability and validity checking, multiple regression analysis, ANOVA, and hypothesis testing. The analyzed data has been presented in the form of a table. The study finds out a strong impact of the Covid-19 pandemic on the work-life balance of women in Bangladesh. Covid-19 has the greatest impact on job stress, job satisfaction, and productivity of women and raises a need for flexibility, workplace support, and work-life balance policy for employees. This study suggested that every organization should have a work-life balance policy which is necessary to maintain a healthy working environment for employees who will improve productivity and job satisfaction of employees.
\end{abstract}

Keywords: Women, Work-Life balance, Job stress, Job satisfaction, Productivity, COVID-19, and Bangladesh.

\section{INTRODUCTION:}

In Bangladesh, a large portion of economic activities are carried out by women including household and care activities, agriculture, education, industries and service sectors. The participation of women in the labor force has been increasing faster than that of men. In 2010, the female labor force participation rate was 36 per cent, which is about 4.5 times higher than what it was in 1983-84. The calculable worth of women's unpaid non-SNA activities was similar to seventyseven percent of Bangladesh's GDP in FY2013-14.
Over four million ladies square measure utilized within the readymade apparel industry, whereas thirty-five p.c of our ladies hold bank accounts. Women's contribution to the value growth is thirty-four p.c in Bangladesh (The Asian Age, 2017). Recently, the most crying issue for a working woman is to maintain balance between her personal and professional life. Work-life balance is a situation where a person can equally fulfill the demands of his/her personal, professional and family life without any intervention. Tomazevic et al. (2014) viewed work life balance as the effective 
combination of professional life with personal obligations to create harmony. It has both positive and negative consequences for both employees and employer. Proper balance of work-life helps employees to get motivation and job satisfaction while imbalance creates dissatisfaction and stress. Purohit, (2013) highlighted that work life balance program has both individual and organizational benefits. Effective work life balance program facilitate relationship between employer and employees for mutual benefit. Employees with balanced work-life are more satisfied and they can perform better. There is a negative relationship between work-life conflict and job satisfaction. Women generally earn less compared to men and they have greater job insecurity. As women have to take on greater care demands at home, they get less time to develop their professional life (Orozco, 2020).

In January 2020 the World Health Organization (WHO) announced a new disease caused by coronavirus, COVID-19, to be a Public Health Emergency of International Concern. World Health Organization declared that there's a high risk of COVID-19 spreading to different countries around the world. In March 2020, the United Nations agency created the assessment that COVID-19 is characterized as an outbreak (WHO, 2020). in step with the Organization for Economic Cooperation and Development (OECD), female area unit notably exposed to the current crisis as they're on the frontlines of the fight against the virus itself, creating up seventieth of worldwide aid employees and the maximum amount as ninety-fifth of long-run care employees (OECD, 2020).

Now-a-days, they need to be more careful about their children and family members to keep them away from infection of coronavirus. Besides there are threats of loss of job, lower income which creates job insecurity and financial crisis for them. Many private organizations in Bangladesh are not paying their employees full salary during COVID-19 lockdown. Some are sacking their employees to maintain their operating cost. These also possess financial and mental stress on female employees especially when they are the only earning member of their families (The Daily Star 2020). Many researchers have studied about the causes of imbalance of work-life of female in several times, but very few/none of them have studies about the UniversePG I www.universepg.com impact of COVID-19 pandemic on women's normal work-life balance. This study points out the impact of COVID-19 on the work-life of female employees in Bangladesh working in different (Teaching, Banking, Healthcare, Ready Made Garments industries, Public and Private Corporations, Government Service and Entrepreneur) sectors (Rafiquzzaman, 2020).

\section{Literature Review}

\section{Work-Life Balance of Women during COVID-19}

According to Amstad et al. (2011) stressful environment, lack of support from manager and long working hours can create imbalance between work and life. Work and family contradiction has more influence in work related outcomes than family related outcomes. Davidson, (2014) identifies six main components of work-life balance such as self, time, stress, change, technology, and leisure management types. Generally, to realize winning work-life balance, someone should receive the foremost eventful physiological necessities (sufficient sleep, balanced nutrition additionally as exercising). Besides, the time ought to be managed optimally between job obligations and private problems. EWCS, (2000) reveals that the number of labors created by associate degree workers incorporates a baleful result on health (Fagan et al., 2011). Khairunneezam et al. (2017) describe Work-life balance as a functioning concept that chains the energies of employees to divide their locus of attention, time, and dynamism between work and also the different necessary aspects of their lives. In step with Isa et al. (2015) Work-life balance isn't just time divided between work-life and nonwork-life that has to be accomplished by reducing the clash between these two territories and leveling the many roles and tasks. Many evidences on the impact of COVID-19 shows that women's economic and productive lives are negatively affecting during COVID-19 pandemic. Such impact already limits women's' ability to support themselves and their families (ILO, 2020). The challenges women face is complex and interrelated. Women's financial activities may be hindered by unequally distributed domestic burdens (Flynn, 2020)

\section{Job Satisfaction}

Job satisfaction is that the level of happiness someone feels concerning his or her job. This sense is especially 
supported by a personality's perception of satisfaction. Job satisfaction is influenced by an individual's ability to finish needed tasks, the amount of communication in a corporation, and also the method management treats workers (Adikaram, 2016). In a study of Indian public sector banks Kumari, (2012) finds out a remarkable relation between work-life balance and job satisfaction and these varies from male and female. Her study has practical significance for improving staff commitments, productivity and retention of employees. A research conducted by Yadav \& Dabhade, (2013) to analyze the relationship between work life balance and job satisfaction of the working women over 150 women from education and banking sector. The results show a strong relationship between work life balance and job satisfaction. There's a generous link between work-life balance and job satisfaction among operating adults with gender and race as moderators among operating sectors too (Lee and Noor, 2017). According to Westover et al. (2019) satisfied workers are motivated to productivity, higher service delivery, quality of work which is helpful to develop a firm's effectiveness and success while unsatisfied workers are tend to be absent, late for work, and employee turnover is high. Nijanti et al. (2016) confirm that besides that the 2 weighty ideas area unit reticular for work life balances action and delight.

\section{Productivity}

Several empirical students have conducted studies on the impact of work-life balance on employees' productivity (Sivatte et al., 2015; Fapohunda, 2014; Greenhaus et al., 2003; Bloom et al., 2006). Correct identification of work-life balance has become pervasive among workers any as their employers. Most researchers have extensively investigated the work-life programs as versatile schedules, upbeat programs, and kid care services in many companies (Sivatte et al., 2015). The key performance indicators of the project's success any as a result of the employee satisfaction unit budget, technology, and adaptableness (Telefilm North yank nation, 2012). The factors unit closely associated with the work-life balance plan, as a result of they're going to have an impression on the diligence and efforts of workers. Therefore, McMahon and Pocock, (2011) advocate that managers 'seek feedback from staff', 'identify future needs' and 'revise provisions as appropriate'. To boot, it had been betterknown that the key performance indicators of workers among the film production trade unit ability, timemanagement, and proficient skills (ibid). The mentioned ways in which might demonstrate the support of workers, encourage the employees/staff and increase the performance level of a worker which can impact on the company's performance.

\section{Job Stress}

Employees' faces family related depression, stress, burnout, general psychological strain for work life conflict (Allen, 2000). In a study, Amstad et al. (2011) explain that stressful environment, lack of support from manager and long working hours can create imbalance between work and life. Work and family contradiction has more influence in work related outcomes than family related outcomes. Employees face depression and become overwhelmed for imbalance of work-life. Organization should keep work environment attractive and flexible to maintain balance. Many private organizations in Bangladesh are not paying their employees full salary during COVID19 lockdown. Some are sacking their employees to maintain their operating cost. These also possess financial and mental stress on female employees especially when they are the only earning member of their families. (The Daily Star, March 2020). Organizations have their own reason as many of them are facing financial crisis, less income and so on. As regards stress management, workers area unit obligated to keep up serenity and management tension in troublesome things associated with family issues or stress at work. Moreover, associate degree workers ought to seamlessly adapt to changes at work and reception, to beat them while not tension. Additionally, the event of technologies helps workers to be a lot versatile, productive and economical. a corporation should be answerable for rest, comfort, and gratification (Tremblay, 2012).

\section{Flexibility}

Employees face depression and become overwhelmed for imbalance of work-life. Organization should keep work environment attractive and flexible to maintain balance (Hutcheson, 2012). Doble and Supriya, (2010) 
suggested to adopt family friendly practices to improve productivity, improve quality of world and family life. They also proposed to introduce flexi time, home working and child care facilities in organization. Mcnall et al. (2010) conducted the study to analyze the relationship between flexible work arrangement and job satisfaction and the finding is that greater the flexible work arrangements provided the more will be the satisfaction among employees. However, the case study explored by Doherty and Manfredi, (2003) targeted the organization that not alone provides $\mathrm{pr}$ flexibility to part-time members of employees but also introduces taxing work that deteriorates the performance and productivity of workers. As a result, the organization fails to appreciate property work-life balance. However, Arizona Employers' Council, Inc. (henceforth AEC) argues that written policies as versatile time plans, set in keeping with company needs and employee's analysis, might minimize potential issues. Besides, Eikhof et al. (2007) cite that "work can have an enfeebling impact on life" and introduces various solutions to the matter with time flexibility.

\section{Workplace support}

Jang, (2008) conducted research on working parents and the result focuses on formal and informal workplace support to enhance employees' wellbeing with their children. A study conducted on female doctors finds out that gender disparity and obstacles like retention of employment, workplace insecurity in rural areas are major challenges for female doctors (Hossain et al., 2019). According to Alliance for Work-Life Progress (AWLP, 2011) employers ought to offer support and edges for workers in high-quality child care and senior care. Rantanen et al. (2011) assert that the impact of a thriving dependent care support provides less stress and higher health of workers which will be propitiously mirrored on productivity. Additionally, health and eudemonia approaches within the geographical point area unit a symbol of effective work-life. Such programs as 'employee assistant programs, health promotion initiatives, fitness center membership still as seminars with employees' area unit the illustrative samples of sturdy work-life balance. Meanwhile, structured support still as paid and unpaid time without work classes area unit elementary to the thriving work-life. Finally, so as to realize shut alignment between worker and management to overhead barriers of full engagement and productivity, the employees ought to be concerned in structure community and follow structure culture (AWLP, 2011).

\section{Work-Life Balance Policy}

Lazar, (2010) focuses on benefit of good practice of work-life balance for both business and employees. Business benefited through recruitment, improved retention, easier service delivery, skilled and experienced workforce etc. On the other hand, employees can spend quality time at home with family and children. Purohit, (2013) highlighted that work life balance program has both individual and organizational benefits. Effective work life balance program facilitate relationship between employer and employees for mutual benefit. Goyal and Agrawel, (2015) explain work life policy and program as an investment for improving productivity, customer service, better health, flexible working, reducing absenteeism and satisfied and motivated workers in banking sectors. However, if a woman is working lady, she expected to do multi task such as take care of family, do household chores etc. Working ladies refers to those in paid employment like lawyers, nurses, doctors, teachers, secretaries, daily wage laborers, etc. (Gouri Prabha, 2019). Rani et al. (2011) conducted the study to judge the connection between work life balance and employee's satisfaction. Results indicated job satisfaction have positive relationship with work life balance and negative relationship with work recognition, relationship with subordinate $\&$ supervisor and task at work.

\section{Work-Family Conflict}

In comparison with men, women face more difficulties in balancing work and life as they have responsibilities towards family, at the same time need to take care of children, fulfill domestic duties, these often creates barrier to their career advancement (Mazerolle and Barrett, 2018). Murthy and Shastri, (2015) focus out parenting issues in their study. They pointed out that female employees need more time for children and also for the spouse. Sometimes they face role conflicts which make them hesitate about how good they are as a mother or as a daughter-in-low. Supervisory support 
is important in order to maintain work-life balance. Superior support is vital so as to keep up work-life balance. Collateral management is required to attenuate the work-life conflict (Beutell and college 2010). In line with European Agency for Safety and Health at Work, work-family conflict is AN outcome of emotional or physical strain obtained at work that affects families' stability (henceforth EU-OSHA). The results of the conflict unit supported such components as time, involvement and satisfaction balances. Moreover, the high level of work-life conflict may cause depression, "physical ailments", "somatic complaints" and "incidence of hypertension" (Googins, 1991; Frone et al., 1997; Burke, 1988; Grant-Vallone and Donaldson, 2001).

\section{Health and Safety issues}

According to Fapohunda, (2014) the number of times spent at work is that the main characteristic of worklife balance. Scholastic findings show however the quantity of excessive operating hours affects employees' health, undermines their safety, and facilitates stress. To exemplify, such overload contributes to serious cardiovascular diseases, like strokes and heart attacks, all presumptively ensuing from chronic workstress, inconsistent and extended shifts, and abuse (Burke and Cooper, 2008; Chandola et al., 2008; Knuttson et al., 1986; Fagan et al., 2011). The challenges women face is complex and interrelated. Women's financial activities may be hindered by unequally distributed domestic burdens (Flynn, 2020). Moreover, violence against girls and ladies square measure increasing globally because the COVID-19 pandemic combines with economic and social stress (Human Rights Watch, 2020; Nahid, 2021). According to World Health Organization (WHO, 2020), one out of three women in the world experience physical or sexual violence during their lifetime and this is also holding true for the coronavirus outbreak.

\section{Conceptual Framework}

\begin{tabular}{|c|c|}
\hline Independent Variables \\
\hline Job Satisfaction \\
\hline Productivity \\
\hline Job Stress \\
\hline Flexibility \\
\hline Workplace Support \\
\hline Work-Life Balance Policy \\
\hline Work-Family Conflict \\
\hline Health and Safety Issues \\
\hline
\end{tabular}

Fig 1: Conceptual Framework of the research.

\section{Objectives of the Study}

The primary concern of this study is to find out the Factors affecting Work-life Balance of working women in Bangladesh during COVID-19 pandemic. The secondary concerns are -

- To find out whether COVID-19 outbreak possess any kind of danger regarding women`s physical and mental health.

- To find out if their productivity is affected by COVID-19 pandemic.

- To find out if they have flexible work schedule during COVID-19.

UniversePG I www.universepg.com

\section{Hypothesis}

H0: There is no impact of COVID-19 on Work-Life Balance of women in Bangladesh.

H1: There is a strong impact of COVID-19 on WorkLife Balance of women in Bangladesh.

\section{METHODOLOGY:}

Research methodology is the specific procedures or techniques used to identify, select, process, and analyze information about a topic. In a research paper, the methodology section allows the reader to critically evaluate a study's overall validity and reliability (David Wilkinson, 2020). The current research is a descriptive research. This research study has been 
conducted among the women working in different public and private organizations (Teaching, Banking, Healthcare, Ready Made Garments industries, Public and Private Corporations, Government Service and Entrepreneur) in Bangladesh based on random sampling in which 105 female employees have been selected as sample.

This study is based on both primary and secondary data. For Primary data collection, pertinent information has been gathered by surveying among the working women. Both questionnaire and interview secessions have been conducted to gather primary data. All of the items in the questionnaire have been measured on 5point Likert scale ( $1=$ strongly disagree, $2=$ disagree, $3=$ neutral, $4=$ agree and $5=$ strongly agree).

Interview secession has been conducted on 30 respondents working in different private and public organizations in Bangladesh. For secondary research, relevant literature from books, articles, newspapers, and magazines have been collected. Descriptive statistics are used for analyzing data including Reliability, Multiple Regression analysis, ANOVA and Hypothesis test in SPSS 20 version.

Table 1: Identification of Variables

\begin{tabular}{|c|c|c|}
\hline Code & Variables & Sources \\
\hline DV & Work-Life Balance & $\begin{array}{l}\text { Amstad et al., 2011; Davidson, 2014; EWCS, 2000; Fagan et al., 2011; } \\
\text { Khairunneezam et al., 2017; Isa et al., 2015; Flynn, } 2020 .\end{array}$ \\
\hline V1 & Job Satisfaction & $\begin{array}{l}\text { Adikaram, 2016; Kumari, 2012; Yadav \& Dabhade, 2013; Lee and Noor, } \\
\text { 2017; Westover et al., 2019; Njanti et al., } 2016 .\end{array}$ \\
\hline $\mathrm{V} 2$ & Productivity & $\begin{array}{c}\text { Sivatte et al., 2015; Fapohunda, 2014; Greenhaus et al., 2003; Bloom et } \\
\text { al., 2006; McMahon and Pocock, } 2011 .\end{array}$ \\
\hline V3 & Job Stress & $\begin{array}{l}\text { Allen, 2000; Amstad et al., 2011; Tremblay, 2012; The Daily Star, } \\
\text { March } 2020 .\end{array}$ \\
\hline V4 & Flexibility & $\begin{array}{l}\text { Hutcheson, 2012; Doble, 2010; Mcnall et al., 2010; Doherty and } \\
\text { Manfredi, 2003); Eikhof } \text { et al., } 2007 .\end{array}$ \\
\hline V5 & Workplace support & Jang, 2008; Hossain et al., 2019; Rantanen et al., 2011; AWLP, 2011. \\
\hline V6 & $\begin{array}{l}\text { Work-Life Balance } \\
\text { Policy }\end{array}$ & $\begin{array}{l}\text { Lazar, 2010; Purohit, 2013; Goyal and Agrawel, 2015; Gouri, 2019; } \\
\text { Rani et al., } 2011 .\end{array}$ \\
\hline V7 & Work-Family Conflict & $\begin{array}{l}\text { Mazerolle and Barrett, 2018; Murthy and Shastri, 2015; Beutell and } \\
\text { College, 2010; Fapohunda, } 2014 .\end{array}$ \\
\hline V8 & Health and Safety issues & $\begin{array}{l}\text { Fapohunda, 2014; Burke and Cooper, 2008; Chandola et al., 2008; Fagan } \\
\text { et al., 2011); Flynn, 2020; Human Rights Watch, 2020; WHO, } 2020 .\end{array}$ \\
\hline
\end{tabular}

\section{Analysis and Interpretation}

Reliability and Validity of data - Reliability refers to the consistency of set of items in measuring the study variables (Cooper and Schinder, 2001). Cronbach's alpha is commonly used method to measure the reliability or internal consistency that is, how closely related a set of items are as a group (Cooper \& Schinder, 2001). The satisfactory value in Cronbach's alpha is required to be more than 0.60 to be reliable (Malhotra, 2002). In this study, Cronbach's alpha is .880 (Table 2), which indicates a satisfactory level of internal consistency for the scale.
Table 2: Reliability Statistics

\begin{tabular}{|c|c|c|}
\hline $\begin{array}{c}\text { Cronbach's } \\
\text { Alpha }^{\mathrm{a}}\end{array}$ & $\begin{array}{c}\text { Cronbach's Alpha Based } \\
\text { on Standardized Items }^{\mathrm{a}}\end{array}$ & $\mathbf{N}$ of Items \\
\hline .880 & .880 & 8 \\
\hline
\end{tabular}

\section{Regression Analysis}

Model Summary - The value of R Square (0.850) and $\mathrm{R}$ (0.922) shows that there is strong association between the set of independent variables and the dependent variable with the standard error of 0.403 (Table 4). In additions, the Table 3 implies that the work-life balance of women during COVID-19 in 
Bangladesh is $85 \%$ dependent on Job Satisfaction, Productivity, Job Stress, Flexibility, Workplace Support, Work-Life Balance Policy, Work-Family Conflict, Health and Safety Issues. The rest only $15 \%$ is dependent on some others factors that are not considered by the researcher in this study.

Table 3: Regression Model Summary

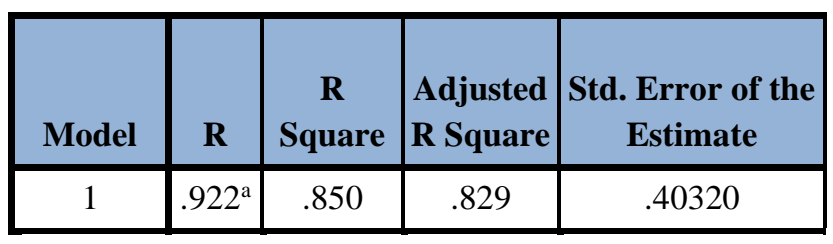

Source: SPSS output

Table 4: ANOVA

\begin{tabular}{|cc|c|c|c|c|c|}
\hline \multicolumn{2}{|c|}{ Model } & Sum of Squares & Df & Mean Square & F & Sig. \\
\hline 1 & Regression & 18.765 & 8 & 5.254 & 38.230 & $.000^{\mathrm{a}}$ \\
& Residual & 91.197 & 97 & .137 & & \\
& Total & 109.962 & 105 & & & \\
\hline
\end{tabular}

Source: SPSS output

a. Predictors: (Constant), Job Satisfaction [V1], Productivity [V2], Job stress [V3], Flexibility [V4], Workplace Support [V5], Work-Life Balance policies [V6], Work-Family conflict [V7], Health issues [V8].

b. Dependent variable: Work-Life Balance during Covid-19 pandemic.

\section{Regression Coefficients}

In Table 5, since the beta values are the standardized versions of the b-values and are directly comparable, these values may be used to infer regarding the relative importance of each predictor or independent variables to the model. In other words, the beta coefficients could be used to explain the relative importance of the 8 dimensions or factors (v1 to v8 i.e., independent variables) in contributing to the variance in the factors affecting work-life balance of women in Bangladesh during Covid-19 pandemic.

The application of the beta-values in the multiple regression model equation (YCCT $=\beta 0+\beta 1 \mathrm{v} 1+\beta 2 \mathrm{v} 2$ $+\beta 3 \mathrm{v} 3+\beta 4 \mathrm{v} 4+\beta 4 \mathrm{v} 5+\beta 4 \mathrm{v} 6+\beta 4 \mathrm{v} 7+\beta 4 \mathrm{v} 8$ Or, $=$ $.194+.379+.491+.875+.229+.279+.135+.262$ $+.185)$ interprets this model to mean that for every increase of one unit in v1, assuming the effects of v2 to v8 be held constant, factors affecting work-life balance of women in Bangladesh during Covid-19 pandemic would increase by 0.229 . Likewise, should the effects of other components be held constant, a single unit increase in v2 would result in a 0.334 increase in UniversePG I www.universepg.com a. Predictors: (Constant), Job Satisfaction [V1], Productivity [V2], Job stress [V3], Flexibility [V4], Workplace Support [V5], Work-Life Balance policies [V6], WorkFamily conflict [V7], Health issues [V8].

\section{ANOVA test}

The $\mathrm{F}$ value of the test for the data is 38.230 . The $\mathrm{p}$ value associated with this $F$ value which is .000 which is lower than the alpha value 0.05 (Table 4). In additions, The Table $\mathbf{4}$ implies that there is significant influence of these independent variables on the dependent variable and the model applied is significantly good to predict the dependent variable.

factors affecting work-life balance of women in Bangladesh during Covid-19 pandemic. Similarly, being other components held constant a single unit increase in v3 to v8 would lead to a $.542, .210, .295$, $.140, .222$ and .169 increase respectively in the factors affecting work-life balance of women in Bangladesh during Covid-19 pandemic.

As far as the relative importance of the 8 WLB dimensions is concerned, v3: (Beta $=0.542)$ followed by v7: (Beta=0.334), v1: $($ Beta=0.299), v5: $($ Beta= 0.295), v7: $($ Beta=0.222), v4: $($ Beta=0.210), v8: $($ Beta $=0.169)$ and v6: $(B e t a=0.140)$ are all important in the factors affecting work-life balance of women in Bangladesh during Covid-19 pandemic. Again, since there is more than one predictor (independent variables), the magnitude of the t-value in conjunction with the significance has been considered to assess the overall contribution to the model. Based on the decision rule "the greater the t-value, the greater the contribution of the predictor", it is seen that $\mathrm{v} 3:(\mathrm{t}=11.009)$ followed by v1: $(\mathrm{t}=8.529), \mathrm{v} 7:(\mathrm{t}=3.687), \mathrm{v} 4:(\mathrm{t}=2.894), \mathrm{v} 5$ : $(\mathrm{t}=2.788), \mathrm{v} 2:(\mathrm{t}=2.390), \mathrm{v} 8:(\mathrm{t}=2.202)$ and $\mathrm{v} 6:(\mathrm{t}=$ 
Table 5: Co-efficients ${ }^{\mathrm{a}}$

\begin{tabular}{|c|c|c|c|c|c|}
\hline \multirow[b]{2}{*}{ Model } & \multicolumn{2}{|c|}{ Unstandardized Coefficients } & \multirow{2}{*}{$\frac{\text { Standardized Coefficients }}{\text { Beta }}$} & \multirow[b]{2}{*}{$\mathbf{T}$} & \multirow[b]{2}{*}{ Sig. } \\
\hline & $\mathbf{B}$ & Std. Error & & & \\
\hline (Constant) & .194 & .268 & & .725 & .471 \\
\hline Job Satisfaction (v1) & .379 & .066 & .299 & 8.529 & .000 \\
\hline Productivity (v2) & .491 & .122 & .334 & 2.390 & .020 \\
\hline Job stress (v3) & .875 & .218 & .542 & 11.009 & .000 \\
\hline Flexibility (v4) & .229 & .079 & .210 & 2.894 & .005 \\
\hline Workplace Support (v5) & .279 & .100 & .295 & 2.788 & .007 \\
\hline Work-Life Balance policies (v6) & .135 & .062 & .140 & 2.188 & .033 \\
\hline Work-Family Conflict (v7) & .262 & .074 & .222 & 3.687 & .000 \\
\hline Health issues (v8) & .185 & .089 & .169 & 2.202 & .041 \\
\hline
\end{tabular}

Source: SPSS output

a. Dependent Variable: Work-life balance during Covid-19

2.188) are all significant predictors or independent variables of the factors affecting work-life balance of women in Bangladesh during Covid-19 pandemic. In this regard, from the t-values it can be also concluded that $\mathrm{v} 3$ has a greater impact on the outcome (i.e., CCT) than v1, v7, v4, v5, v2, v8 and v6.

In summary, it can be stated that all underlying dimensions are positive and therefore are significant. Thus, the result of multiple regression analysis rejects the null hypothesis (H0) that "There is no impact of COVID-19 on Work-Life Balance of women in Bangladesh." and proves or accepts the alternative hypothesis (Ha) that "There is a strong impact of COVID-19 on Work-Life Balance of women in Bangladesh". So, there is a relationship as expected. So, the regression model achieved a satisfactory level of goodness-of-fit in predicting the variance of CCT in relation to the 8 predictors or independent variables, as measured by the above-mentioned R, R2, and adjusted $\mathrm{R} 2, \mathrm{~F}$ ratio, beta and $\mathrm{t}$ values. In other words, at least one of the 8 predictors or independent variables of the CCT is important in affecting the work-life balance of women during Covid-19 pandemic in Bangladesh.

\section{CONCLUSION AND RECOMMENDATIONS:}

Work-life balance may be a construct that supports the efforts of workers to separate their time and energy between work and also the alternative vital aspects of their lives. Work-life balance may be a daily effort to create time for family, friends, community participation, spirituality, personal growth, self-care, and alternative personal activities, additionally to the stress of the Work-life balance may be a construct that supports the efforts of workers to separate their time and energy between work and also the alternative vital aspects of their lives. Work-life balance may be a daily effort to create time for family, friends, community participation, spirituality, personal growth, self-care, and alternative personal activities, additionally to the stress of the work. Workers are happier after they are able to balance their work life demands. Management additionally expertise improve relationship with workers. this study finds out that Women`s work-life balance is generally addicted to job stress, job satisfaction, flexibility, work support throughout Covid-19 pandemic. Moreover, correct work-life balance policies of the organization will promote a healthy operating setting wherever organization offers higher opportunities for feminine workers.

This study concludes that job life balance philosophy is related to real advantages for a corporation. This is often as a result of correct balance between work and life can increase job satisfaction and productivity of feminine workers, scale back their stress level and work-family conflict and guarantee versatile operating setting. This study recommended that every organ- 
ization should have work-life balance policy which is necessary to maintain a healthy working environment which will improve productivity and job satisfaction of employees. Management support for workers work life balance additionally fosters a decent relationship between the workforce and management that improve effective communication within the organization.

\section{ACKNOWLEDGEMENT:}

I thank the previous authors for their contributions in this field of study. I also thank all those women who have spent their valuable time in the questionnaire survey informal interview sessions.

\section{CONFLICTS OF INTEREST:}

There is no conflict of interest in the publication of this manuscript.

\section{REFERENCES:}

1) ACAS. (2015). Flexible working and work-life balance. Available from https://journals.sagepub.com/doi/abs/10.1177/09 $\underline{50017015570724}$

2) Adikaram, D.S.R. (2016). 'Impact of work life balance on employee job satisfaction in private sector commercial banks of Sri Lanka', International J. of Scientific Research and Innovative Technology, 3(11): 17-31. https://ijsrit.com/uploaded_all_files/3554395309 nn2.pdf

3) Allen, T. (2000). 'Consequences Associated with Work-to-Family Conflict', Journal of Occupational Health Psychology, 5: 278-308. www.dx.doi.org/10.1037//1076-8998.5.2.278

4) Amstad, F., Meier, L., Fasel, U., Elfering, A., Semmer, N. (2011). 'A Meta-Analysis of Work-Family Conflict and Various Outcomes with a Special Emphasis on Cross-Domain versus Matching-Domain Relations', J. of Occupational Health Psychology, 16: 151-169. www.dx.doi.org/10.1037/a0022170

5) Beutell, N. and College, I. (2010). 'The Causes and Consequences of Work-Family Synergy: An Empirical Study in the United States', International J. of Management, 27: 650-664. https://www.researchgate.net/publication/259467 $\underline{246}$
6) Bloom et al., (2006). 'Management Practices, Work-Life Balance, and Productivity: A Review of Some Recent Evidence', Centre for Economic Performance. The London School of Economics and Political Science.

http://cep.lse.ac.uk/management/worklifebalance research.pdf

7) Chandola, T., Bartely, M., Marmot, M. and Michikazu, S. (2004). Does Conflict between Work and Home Explain the Effect of Multiple Roles on Mental Health? A Comparative Study in Finland, Japan and the UK. International J. of Epidemiology, 33(4): 884-893. https://academic.oup.com/ije/article/33/4/884/66 $\underline{5535}$

8) COVID-19: Thailand to require all travelers to obtain health certificate for entry from Mar 22, Channel News Asia, 20 March 2020.

9) Deery, M. and Jago, L. (2015). Revisiting talent management, work-life balance and retention strategies, International J. of Contemporary Hospitality Management. 27(3): 453472.

https://www.emerald.com/insight/content/doi/10. 1108/IJCHM-12-2013-0538/full/html

10) Doble N., Supriya M. V. (2010). 'Gender Differences in the Perception of Work-Life Balance', Econ Papers, Management 2010, 5(4): 331-342.

https://econpapers.repec.org/article/mgtyoumng/ v_3a5_3ay_3a2010_3ai_3a4_3ap_3a331-

342.htm

11) Doherty, L. and Manfredi, S. (2006). "Action research to develop work-life balance in a UK university", Women in Management Review, 21(3): 241-259.

https://www.ingentaconnect.com/content/mcb/05 3/2006/00000021/00000003/art00005

12) Fapohunda, Tinuke. M (2014). 'An Exploration of the Effects of Work Life Balance on Productivity', Journal of Human Resources Management and Labor Studies, 2(2): 71-89. http://jhrmls.com/vol-2-no-2-june-2014-abstract5-jhrmls

13) Fagan, C., et al. (2012). The influence of working time arrangements on work-life inte- 
gration or 'balance.' Conditions of Work and Employment Branch, 32, 1-60.

14) Fagan C., Walthery P. (2011). Job Quality and the Perceived Work-Life Balance Fit between Work Hours and Personal Commitments: A Comparison of Parents and Older Workers in Europe. In: Drobnič.

15) Fapohunda, (2014). 'Gender Influences in Work Life Balance: Findings from Nigeria', Global Journal of Human Resource Management, 2(2): 25-39.

https://www.researchgate.net/publication/281593 $\underline{309}$

16) Flynn L., Laura A. and Harshika G. (2020). 'Seven Key Issues Affecting Women and Girls During the COVID-19 Pandemic-And What You Can Do About Them'.

17) Gouri Prabha P.V. (2019). 'Challenges and Problems of a Working Woman' International Journal of Innovative Research and Advanced Studies (IJIRAS), 6(5): 118-119.

https://www.researchgate.net/publication/335686 $\underline{812}$

18) Goyal K.A., Agrawel A. (2015). "Issues and Challenges of Work Life Balance in Banking Industry of India", Pacific Business Review International, 8(5): 113-118.

http://oaji.net/articles/2016/3050-1456206153. pdf

19) Greenhaus et al. (2003). 'The relation between work-family balance and quality of life', Journal of Vocational Behavior 63: 510-531. https://www.sciencedirect.com/science/article/ab s/pii/S0001879102000428

20) Guillén S., A.M. (2011). Work-Life Balance in Europe. Work and Welfare in Europe. Palgrave Macmillan, London. https://doi.org/10.1057/9780230307582_4

21) HRD, (2020). Human Rights Dimensions of COVID-19 Response, Human Rights Watch, 19 March 2020.

https://www.hrw.org/news/2020/03/19/humanrights-dimensions-covid-19-response

22) Hutcheson, P. (2012). Work-Life Balance. IEEE-USA, USA.

23) Isa et al, (2015). 'Individual, Organizational and Environmental Factors Affecting Work-
Life Balance', Asian Social Science; 11(25); 2015, E-ISSN 1911-2025.

www.dx.doi.org/10.5539/ass.v11n25p111

24) Kumari L. (2012). 'Employees' Perception on Work Life Balance and It's Relation with Job Satisfaction in Indian Public Sector Banks', International Journal of Engineering and Management, IJEMR, 2(2): 1-13.

25) Lazar, I., Osoian, C., \& Ratiu, P. (2010). 'The role of work-life balance practices in order to improve organizational performance', European Research Studies J., 13(1): 201-214. https://ideas.repec.org/a/ers/journl/vxiiiy2010i1p 201-214.html

26) Lee and Noor (2017). 'Outside of Official Working Hours: The Impact on Work-life Conflict and Work Engagement' IOSR Journal of Mobile Computing \& Application (IOSRJMCA), 5(3): e-ISSN: 2394-0050. http://www.iosrjournals.org/iosr-jmca/papers/ Vol5-Issue3/B05030914.pdf

27) Mazerolle and Barrett, (2018). 'Work-Life Balance in Higher Education for Women: Perspectives of Athletic Training Faculty', Athletic Training Education J., 13(3): 248258.

https://meridian.allenpress.com/atej/article/13/3/ 248/60949/Work-Life-Balance-in-Higher-Edu cation-for-Women

28) McMahon and Pocock (2011). 'Work, Life and VET Participation amongst Lower-Paid Workers. NCVER Monograph Series 05/ 2011', National Centre for Vocational Education Research (NCVER), 2011, 53, ISSN: 1837-065. https://eric.ed.gov/?id=ED521476

29) McMahon, C. and Pocock, B. (2011). Doing things differently: Case Studies of Work-Life Innovation in Six Australian Workplaces. University of South Australia.

http://w3.unisa.edu.au/hawkeinstitute/cwl/docum ents/case-studies.pdf

30) McNall, L.A., Nicklin, J.M., and Masuda, A.D. (2010). 'A Meta-Analytic Review of the Consequences Associated with Work-Family Enrichment', J. of Business and Psychology, 25(3): 381-396. https://doi.org/10.1007/s10869-009-9141-1 
31) Murthy, N.M. and Shastri, S. (2015). 'A quailtative study on work life balance of employees working in private sector', International $J$. of Recent Scientific Research, 6(7): 5160-5167. http://www.recentscientific.com/sites/default/file s/2926.pdf

32) Nahid AHM. (2021). Resistance, unrest, protest and demonstration provoked by COVID-19: a case study of Bangladesh, Asian J. Soc. Sci. Leg. Stud., 3(2), 23-34. https://doi.org/10.34104/ajssls.021.023034

33) Orozco, M. (2020). 'Migrants and the Impact of the COVID-19 Pandemic on Remittances', The Dialogue.

34) Purohit M. (2013). 'A Comparative Study of Work Life Balance in Various Industrial Sectors in Pune Region', International Journal of Marketing, Financial Services \& Management Research, 2(3): 198-206.

35) Rafiquzzaman SM. (2020). Case Study on the Impact of Pandemic COVID-19 in Aquaculture with its recommendations. Am. J. Pure Appl. Sci., 2(2), 36-38. https://doi.org/10.34104/ajpab.020.36038

36) Rani et al. (2011). Work/Life Balance Reflections on Employee Satisfaction, Serbian J. of Management, 6(1): 85-96. https://doi.org/10.5937/sjm1101085R

37) Ruth Eikhof, D. (2007). "Introduction: What work? What life? What balance? Critical reflections on the work-life balance debate", Employee Relations, 29(4): 325-333. https://doi.org/10.1108/01425450710839452
38) Sivatte, I. et al. (2015). 'The impact of worklife culture on organizational productivity', Personnel Review, 44 (6): 883-905. www.dx.doi.org/10.1108/PR-12-2013-0226

39) The COVID-19 Outbreak, (2020). 'Potential Fallout for Sexual and Reproductive Health and Rights', Guttmacher Institute, March 2020.

40) Tomazevic, N., Kozjek, T. and Stare, J. (2014). 'The Consequences of a Work-Family (Im) Balance: From the Point of View of Employers and Employees', International Business Research, 7: 83-100. https://doi.org/10.5539/ibr.v7n8p83

41) Tremblay, (2012). 'Work-Family Balance: Is the Social Economy Sector More Supportive and is this because of its More Democratic Management?' Review of Social Economy, 70(2): 200-232.

https://www.tandfonline.com/doi/abs/10.1080/00 $\underline{346764.2011 .632324}$

42) UK AID, (2020). 'Impact of COVID 19 Pandemic on Violence against Women and Girls', 16 March 2020.

43) UN Women, 'Guidance Note, (2020). 'Addressing the Impacts of the COVID-19 Pandemic on Women Migrant workers.' 18 May. https://www.unwomen.org/en/news/stories/2020/ 3/statemented-phumzile-COVID-19-women-fron t-and-centre.

44) Westover et al., (2019). 'The Role of WorkLife Balance and Worker Scheduling Flexibility in Predicting Global Comparative Job Satisfaction,' International Journal of Human Resource Studies, 9(2): 80-115. https://doi.org/10.5296/ijhrs.v9i2.14375

Citation: Basak S. (2021). Factors affecting work-life balance of women in Bangladesh: a study during COVID19 pandemic, Can. J. Bus. Inf. Stud., 3(3), 38-48. https://doi.org/10.34104/cjbis.021.038048 () क 